\title{
ATG4C wt Allele
}

National Cancer Institute

\section{Source}

National Cancer Institute. AT G4C wt Allele. NCI Thesaurus. Code C114673.

Human AT G4C wild-type allele is located in the vicinity of 1 p31.3 and is approximately 81 $\mathrm{kb}$ in length. This allele, which encodes cysteine protease AT G4C protein, is involved in proteolysis during autophagy. 